\title{
How Does the Foreign Audience Respond to China's Cultural Exchange Programs Abroad: Survey Evidence from the 2011 Terracotta Army Exhibition in Montreal
}

\author{
Wenbin Jiang ${ }^{1,2}$ \& Caiwu $\mathrm{Fu}^{3}$ \\ ${ }^{1}$ National Center for Cultural Industries Research, Central China Normal University, Wuhan, China. \\ 2 The Department of Art History and Communication Studies, McGill University, Montreal, Canada \\ ${ }^{3}$ National Center for Cultural Innovation Research, Wuhan University, Wuhan, China \\ Correspondence: Wenbin Jiang, National Center for Cultural Industries Research, Central China Normal \\ University, Wuhan, Hubei 430079, China. E-mail: dtpercy2000@yahoo.com.cn
}

Received: September 29, 2012 Accepted: October 18, 2012 Online Published: December 31, 2012

doi:10.5539/ass.v9n1p232

URL: http://dx.doi.org/ass.v9n1p232

\begin{abstract}
Considerable negative views of China's rise persist in international opinion, highlighted by criticisms of China's domestic and foreign affairs and concerns of "China threat". To tell China's story to the world, Chinese leaders pay particular attention to international cultural exchanges. How does the foreign public respond to China's cultural exchange program abroad? During the 2011 Terracotta Army exhibition in Montreal, this survey finds a majority of respondents view China's oversea cultural programs positively and favours the idea that cultural exchanges help to improve China's international image, while a substantial number of audience holds either neutral or unfavourable attitudes towards China's international image and lacks knowledge about China and Chinese culture. This paper suggests that China's international cultural exchanges should be maintained and enhanced with a two-pronged approach to provide foreign public with a convincing source of learning about both ancient Chinese culture and contemporary Chinese experience and hence, reduce their doubts and concerns about China's development.
\end{abstract}

Keywords: China, cultural exchanges, international image, Terracotta Army

\section{Introduction}

\subsection{Negative Views of China's Rise in International Opinion}

As the world enters the second decade of the twenty-first century, China's re-emergence as a world power is widely acknowledged, and arguments about China's status have become all the more convincing as Europe struggles with the sovereign debt crisis of many of its member countries, and the United States lost its triple-A sovereign credit rating for the first time in its history(Standard \& Poor's Financial Services LLC, 2011). In contrast to the recession in many economies, the Chinese economy maintains a relatively steady growth, which also brings opportunities for other countries in the world.

However, there is still a considerable amount of negative views of China's rise in international opinion. The notion of "International Opinion" is known as the general consensus by mass media, world publics, international originations and NGOs towards international affairs and issues, which is mainly dominated by western media opinions and reports (X. Liu, 2010). Negative information about China in the international opinion currently can be divided in two aspects. On the one hand, the fears of "China threat" are still a concern highlighted from time to time by western media, scholars and policy makers. Emerged in the early 1990s, the "China threat" theory claims that the rise of China implicates a threat to the stability in both Asia-Pacific region and the rest of the world in aspects of ideology, economy, military, environment, energy, and so on. (Note 1) The recent evidences underlining this concern are seen in the latest security reports published respectively by the Japanese Ministry of Defense and the Office of the Unites States Secretary of Defense, as both reports have cited the "China threat". (Note 2) Some regional issues, such as the South China Sea dispute, have also sparked a new round of accusations on the "China threat" by rival countries in the region recently (Miks, 2011). Among the American mainstream media, the "China threat" had even become a "growing consensus" before Chinese President Hu 
Jintao's visit to the United States in 2011(Rothkopf, 2011). On the other hand, the Western media has been critical of China's domestic politics and foreign policies by covering topics such as human rights abuses, one-party regime, and ethnic riots, etc. News coverage of China by the U.S. media, for example, have been focusing on issues involving tainted Chinese products, ethnic clashes, violence and political unrest in China, as well as disasters, whereas China's economic achievements are "even less visible in the news" (Pew Research Center, 2011a). Figure 1 illustrates the top five weekly China stories covered by the U.S. media in any given week since January 2007. As Zhang (2006) argues, American reporters are motivated by the current politics and ideologies as well as social and political incentives to demonize China as an "enemy." Some empirical studies show that media coverage of China in other Western countries follows almost the same pattern as that in the United States. (Note 3)

\section{THE U.S. MEDIA ON CHINA}

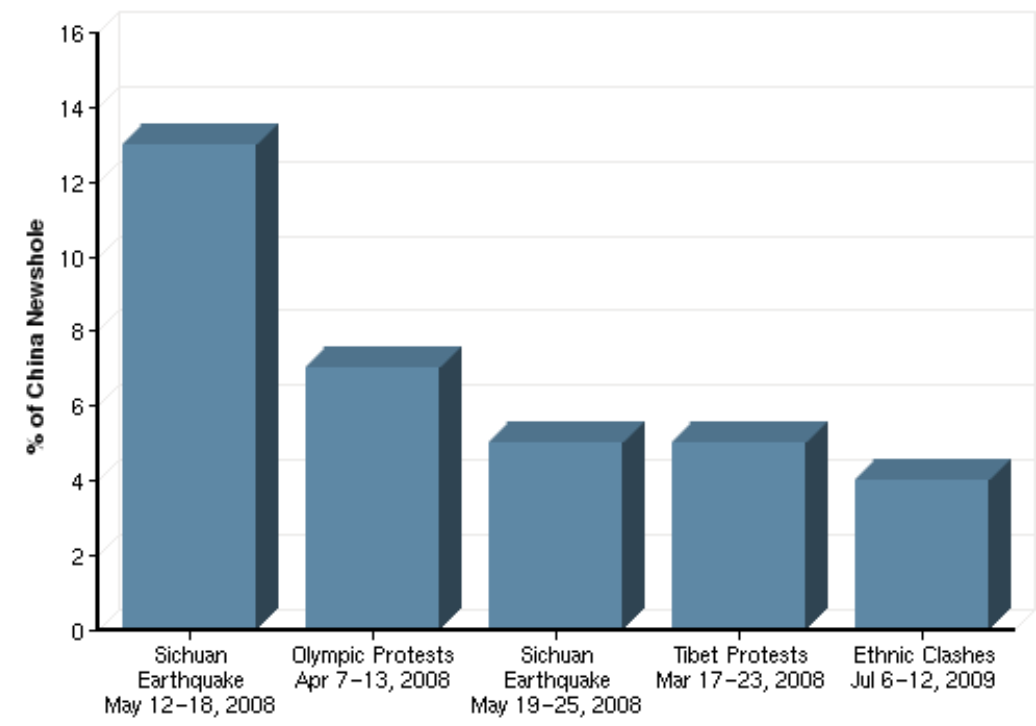

Figure1. The top five weekly China stories since January 2007 (Pew Research Center 2011b)

With negative information filling the media newshole and international opinion, China's image is more likely to be viewed unfavorably by the world publics. According to the latest BBC World Service Country Rating Poll of twenty-two countries around the world, the global average views of China has improved significantly over the year 2011. However, this improvement is mainly because of China's positive economic influence by contrast with the EU's "turmoil" over the year, while China's domestic politics and foreign policy remain largely disapproved by foreign publics. There is an average of $31 \%$ of the respondents holding unfavorable attitudes towards China, and the number of people who do not like China in the United States, Germany, France, Spain, Japan, South Korea and India surpass those who do(BBC World Service, 2012). The surveys conducted by the Pew Research Center (2012) show that Americans not only rank China as their second largest enemy in the world, but also think China's growing economic might is "bad" for the United States.

\subsection{The Chinese Government's Endeavour in International Cultural Exchanges}

It is arguable whether the negative international opinion on China is fair enough or rather biased. The near consensus within Chinese academia, however, contends these rebukes of China in the Western-dominated media and international opinion have been significantly partial and biased due to either anti-communism ideology, the centralism of Europe and America, or the local interests of different countries and groups, hence accurate views of China are reduced by selective reporting and double standards. As a result, Chinese academia has called on the government to take initiative telling China's story to the world, so as to reduce misperception and misunderstanding of China by foreign publics. (Note 4)

In response to this utterance, the Chinese government has been increasingly active in the arena of public diplomacy, which has indeed become increasingly important within China's overall diplomatic strategy (J. Yang, 2011). Public diplomacy, as Ociepka (2008) explained, aims to influence foreign public opinion and shape positive attitudes toward the country through mass communication media and non-mediated channels, such as cultural and educational exchanges. International cultural exchanges, as part of the toolbox of public diplomacy, have been greatly valued by China's policy makers. (Note 5) "Culture as a soft power," as Zhao Shaohua, 
China's Vice Minister of Culture put it, "could win hearts and minds imperceptibly" (Guo, 2011). Cultural diplomacy, interacting with political diplomacy and economic diplomacy, will become an integral part of China's overall foreign policy strategy in the twelfth Five-Year Plan, announced by Yang Jiechi, China's Minister of Foreign Affairs in the 2011 National People's Congress (Xinghua News Agency, 2011).

It is evident that a huge amount of money and effort has been invested into international cultural exchanges by the Chinese government. In recent years China has reached inter-governmental cultural exchange agreements with 145 countries, covering more than eight hundred annual cultural exchange programs in partnership with above one thousand cultural institutes abroad (Xiao Wang, Guo, \& Li, 2010). How does the audience respond to China's oversea cultural exchange programs? Are these cultural programs fulfilling the objectives set by the Chinese government? What can be done to improve the effectiveness of these cultural exchange programs abroad so as to ensure a convincing source of learning about Chinese culture and China for foreign public? Answering these questions involves survey-based empirical research into foreign audience's responses to China's cultural exchange programs abroad.

\section{Literature Review}

Despite debates on whether to see China's rise as threat or peaceful development have been increasing in academic interests, most studies are of theoretical and qualitative analysis from perspectives of China's strategy of soft power, public diplomacy or cultural diplomacy.( Note 6) There is little empirical analysis has been done to understand how the world public views China, and even less has been done to survey the audience of China's cultural exchange programs abroad.

\subsection{Foreign Public's General Attitude towards China}

Comprehensive studies of China's image are usually based on survey reports produced by polling companies. By analyzing the 2008 Pew report, Shaw (2010) found there has been trends of global favorability towards China's hard power and soft power, and he argued that the U.S. should take proactive initiatives to engage China's rising power and sustain the U.S. global leadership. Zhai and Li (2009) argued that the 2008 Pew survey reflected western media value and ideology, while the Chinese public's perception of their country was shaped by Chinese media system. In interpreting the reports issued by Pew, World Public Opinion.org and Globescan in 2009, Ling and Yujia (2010) found the China's power was gaining recognition worldwide but China's domestic and foreign policies incurred much controversy.

Some field studies addressed regional countries' public views of China. Dong, Wang, and Li (2010) found Korean public recognizes the rise of China, but they favored the alliance with the United States to counterbalance China's power. J. Wang (2007) compared the soft powers of Japan and China based on a survey at Osaka Sangyo University, and argued that soft power is underpinned by economic power. Z. Wang and Yang (2009) studied how public in southeast Asia view China based on an regional survey, and suggested that China should cultivate positive images among your people in the region. Based on a survey data during 2000-2010, Khoo (2011) examined the level of regional "fear factors" in Northeast Asia with respect to China's rise.

The rise of China has special implication to the United States in terms of global leadership. Xie and Benjamin (2010) found most Americans were well aware of the rise of China and they favor cooperation and peaceful engagement with China. Rutledge (2008) compared the American's perceptions' of China before and after the Beijing Olympics, and found perceptions of China as an enemy and China's media as inaccurate increased significantly. Gries and Crowson (2010) found that "conservatives" or Republicans perceive greater threat in China's rise than "liberals" or Democrats based on their surveys. K. Liu (2011a) found that American people's perception of China was influenced by their party affiliations and educations, as well as news media.

To sum up, publics around the world are well aware of China's rise as a major power and they generally favor economic cooperation with China. However, world publics are still uncertain about whether China will be a friend or enemy.

\subsection{Foreign Public's Attitudes towards China's Cultural Exchange Programs Abroad}

Confucius Institutes are China's most influential international cultural programs that aim to promote Chinese language and culture overseas, and arguably, to project China's ideology and soft power as well (Starr, 2009). By interviewing the students in the United States, X. Wu (2011) found students' views of China have turned more positive after attending the Confucius Institutes. Based on a survey in Kenya, Wheeler (2012) argued the success of Confucius Institute in Africa is measured by not only the political and social context, but also the attitudes of students and local business community. By analyzing surveys conducted in Confucius Institutes in Japan and Lebanon, Ying $\mathrm{Wu}$ and $\mathrm{Ge}$ (2011) argued that content, religion and communication patterns are key to the 
success of China's cultural promotion overseas.

Chinese martial arts or "Gong Fu" is another Chinese cultural icon that is well known to the foreign public, and hence become a prominent element of China's cultural exchange programs abroad. Several field studies have been done to address the promotion of Chinese martial arts overseas. Based on surveys conducted in several European countries, Long (2007) examined the promotion of Chinese martial art in Europe from the economic point of view. X. Yang (2011) examined the education of Chinese martial arts in universities abroad by interviewing foreign students in China and found that there is a lack of qualified teachers and course materials for education of Chinese martial arts in overseas universities.

In general, the existing empirical studies on China's cultural programs abroad have mostly been contributed to address the promotion of Chinese culture, without much discussion on China's cultural diplomacy and image projection.

\section{Method}

\subsection{Sample}

The aim of this research is to document the opinions from the audience of China's oversea cultural exchange programs. This said, the population of concern is the foreign public who had personal experience of China's cultural exchange programs abroad, instead of the general foreign public, because these actual participants will have more say to the weakness, strength and effectiveness of these programs conducted abroad. To address this research aim, a random sample was drawn from the audience of the "Warrior Emperor and China's Terracotta Army" exhibition, hold in Montreal, Quebec, Canada in 2011.

The Terracotta Army Exhibition abroad is a typical Chinese international cultural exchange program, which can be dated back to the early1980s. Up to now, the Terracotta Army exhibitions have been held in more than forty countries, covering up to seventy cities worldwide with as many as twenty million overseas audiences (Yongqi $\mathrm{Wu}, 2009)$. The exhibitions have served as a bridge for the cultural exchanges between China and foreign countries, and stimulated enthusiasm and interest in Chinese culture worldwide, according toTian (2002, p. 14), the deputy curator of the Mausoleum Site Park. However, the exhibitions abroad have also suffered criticism from Western media and scholars as "having Chinese government involvement" (Paradise, 2009), and some scholars contended that China was practicing "Terracotta diplomacy" with other countries (Adams, 2007; Langley, 2007). Moreover, some protestors put masks and anti-China placards on these 2, 200-year-old statues (Tidy, 2010, pp. 76-80). It is interesting to find out how the audience in Montreal views the exhibition.

Though the research aims to survey "foreign audience", the audience of western countries is the major population of interest. As a member state of the Group of Eight (G8) and The North Atlantic Treaty Organization (NATO), Canada is a typical western country. What is more, the city of Montreal is a multicultural cosmopolis with tourists from all over the world, hence audience from Montreal are more representative of "foreign audience". In addition, this exhibition was held as one of the events celebrating the fortieth anniversary of Sino-Canadian diplomatic relations, which attached significance of cultural diplomacy to the exhibition.

\subsection{Measurement and Procedure}

The questionnaire is mainly consisting of structured questions, which can be categorized into three sections ranging from immediate feelings about the exhibition to in-depth questions concerning the perceptions of Chinese culture, China's national image and China's international cultural exchanges. Taking into account that French is Montreal's official language, the questionnaire was made available in both French and English to cater to respondents of different language preference. For the statistical analyses of survey data, the Predictive Analytics Soft Ware (PASW)18.0 was applied to perform analyses of frequency, multiple response and correlations to generate meaningful relationships between variables.

This survey is an on-the-spot interview, instead of telephone or mail surveys. A total of 317 out of more than three hundred participants completed the questionnaire forms, and of which 304 were considered valid and used for statistical analyses. (Note 7) Reliability analysis was conducted through Cronbach Alpha to test the reliability of the gathered data. The results illustrated that the coefficient alpha is 0.864 and as such is considered adequate as an indication of reliability for basic research (Table 1). (Note 8) 
Table 1. Reliability analysis

\begin{tabular}{|c|c|c|c|}
\hline \multicolumn{4}{|c|}{ Reliability Statistics } \\
\hline \multicolumn{2}{|r|}{ Cronbach's Alpha } & \multicolumn{2}{|c|}{$\mathrm{N}$ of Items } \\
\hline \multicolumn{2}{|r|}{0.864} & \multicolumn{2}{|c|}{36} \\
\hline \multirow{5}{*}{ Cases } & & & \\
\hline & & $\mathrm{N}$ & $\%$ \\
\hline & Valid & 263 & 87 \\
\hline & Excluded $^{\mathrm{a}}$ & 41 & 14 \\
\hline & Total & 304 & 100 \\
\hline
\end{tabular}

a. Listwise deletion based on all variables in the procedure.

\subsection{Demographic Characteristics of Respondents}

The background of the individuals, such as nationality, education, occupation and so on, could influence the representativeness of the survey results. Table 2 gives a picture of the demographic characteristics of the respondents in this survey.

Table 2. The demographic characteristics of the respondents, $\mathrm{N}=304$

\begin{tabular}{lr}
\hline Sex & \\
\hline Male & $44.4 \%$ \\
Female & $55.6 \%$ \\
Age & \\
19 and below & $7.8 \%$ \\
$20-39$ & $44.0 \%$ \\
$40-59$ & $39.0 \%$ \\
60 and above & $9.2 \%$ \\
Nationality & \\
Canada & $68.0 \%$ \\
United States & $5.1 \%$ \\
Western countries other than Canada and the United States & $15.0 \%$ \\
Others & $11.9 \%$ \\
Education & \\
Secondary Education & $1.8 \%$ \\
College & $27.3 \%$ \\
Bachelor & $49.3 \%$ \\
Master & $15.0 \%$ \\
PhD & $5.7 \%$ \\
Others & $0.9 \%$ \\
Occupation & \\
Public Servant & \\
Education/Research & $5.1 \%$ \\
Arts/Culture & $15.4 \%$ \\
NGO & $7.1 \%$ \\
Business & $3.2 \%$ \\
Student & $41.7 \%$ \\
\hline Fron Table 2 we & $27.6 \%$ \\
\hline
\end{tabular}

From Table 2, we can see the following characteristics of respondents:

1) A strong majority of the respondents (88\%) are from Canada, the United States and other Western countries, which meets the survey's target of focusing mainly on Western audiences.

2) A strong majority of the respondents (70\%) have bachelor degrees and above, which ensures the respondents' 
discretion on international issues.

3) A near majority of the respondents (42\%) are from the business sector, which indicates that the respondents represent the general public and are not limited to professionals from the arts and cultural sector; a strong majority of the respondents $(83 \%)$ are young and middle-aged adults; the number of the female respondents $(56 \%)$ is slightly higher than that of the male respondents $(44 \%)$, and hence the age and sex distribution is basically balanced.

\section{Analysis of Survey Results}

\subsection{The Audience's Perception of the Terracotta Army Exhibition}

\subsubsection{The Unique Charm of the Terracotta Army}

Montreal is known as "Canada's Cultural Capital" (Wingrove, 2008). The UNESCO (2006) also entitled Montreal as a "City of Design". The city has a great number of museums throughout the city with all types of exhibitions performed through the year. Why did the audience choose to attend the Terracotta Army exhibition? The audience's motivation was investigated as an initial question in the questionnaire (Table 3):

Table 3. Audience's motivation to attend the exhibition

\begin{tabular}{llll}
\hline \multirow{2}{*}{${\text { You attended this exhibition because of your interests in }{ }^{\mathrm{a}}}^{\mathrm{n}}$} & \multicolumn{2}{l}{ Responses } & \multirow{2}{*}{ Percent of Cases } \\
\cline { 2 - 4 } & $\mathrm{N}$ & Percent & \\
\hline General art and culture & 168 & $46.2 \%$ & $55.4 \%$ \\
Chinese culture in particular & 135 & $37.1 \%$ & $44.6 \%$ \\
China's growing influence & 41 & $11.3 \%$ & $13.5 \%$ \\
Other & 20 & $5.5 \%$ & $6.6 \%$ \\
Total & 364 & $100.0 \%$ & $120.1 \%$ \\
\hline
\end{tabular}

a. Dichotomy group tabulated at value 1 .

Firstly, the survey result indicated that general art and culture represented by the Terracotta Army is the major factor (55\%) that attracts the audience to attend the exhibition. This shows the unique charm of Terracotta Army is appreciated by people of different countries as a shared human memory. Secondly, the particular interest in Chinese culture remains a significant motivation for many participants (45\%). Thirdly, China's increasing global influence also becomes a factor to bring the audience to the exhibition (14\%). As argued by X. Wei (2002), the more powerful a country is, the more possibilities for this country's cultural diplomacy to succeed .

\subsubsection{Wonder and Admiration for Chinese History and Culture}

How do the participants describe their feelings after attending the Terracotta Army exhibition? As the Terracotta Army were described as ancient China's "military machine" and "fierce army" by some media (Guardian, 2007; Johnston, 2007 ), does the participants associate the Terracotta Army with the so-called "militaristic threat" of contemporary China? These questions were responded as follows (Table 4):

Table 4. The audience's immediate feelings about the Terracotta Army

\begin{tabular}{llll}
\hline \multirow{2}{*}{$\begin{array}{l}\text { If you were describing this exhibition to a friend, which word(s) would you } \\
\text { use? }\end{array}$} & \multicolumn{2}{l}{ Responses } & \multirow{2}{*}{ Percent of Cases } \\
\cline { 2 - 3 } & N & Percent & \\
\hline Beauty of the Chinese Arts & 90 & $22.6 \%$ & $32.1 \%$ \\
Great Chinese Culture \& History & 214 & $53.6 \%$ & $76.4 \%$ \\
Growing interest in Chinese culture & 56 & $14.0 \%$ & $20.0 \%$ \\
Militaristic China & 33 & $8.3 \%$ & $11.8 \%$ \\
No particular feeling or interest & 1 & $0.3 \%$ & $0.4 \%$ \\
Other & 5 & $1.3 \%$ & $1.8 \%$ \\
Total & 399 & $100.0 \%$ & $142.5 \%$ \\
\hline
\end{tabular}

a. Dichotomy group tabulated at value 1 .

According to the survey results, what impressed participants the most was the grandeur and splendor of Chinese history and culture, a strong majority of 76 per cent of respondents expressed their deep wonder and admiration. Next, the beauty of Chinese arts demonstrated by the Terracotta Army also impresses the audience( $32 \%)$. it is obvious that the ancient Chinese civilization with its magnificent arts and cultural heritages poses the most popular attraction to foreign audiences. As a result, many within the surveyed audience indicated that they have a 
growing interest in Chinese culture after attending the Terracotta Army exhibition. "To get the foreign audiences interested in Chinese culture is a step forward," said an official from China's Ministry of Culture (Li, 2010). Lastly, a few participants (12\%) associated the Terracotta Army with China's militaristic image, which should be noted by the organizers of similar exhibitions in future.

\subsubsection{Cultural Relics Exhibitions Are not Perceived as Ideological Propaganda}

Some Western scholars and media are suspicious of the Chinese government's claim about the purpose of China's international cultural promotion being simply increasing mutual understandings between the people of China and other countries. For example, China's Confucius Institutes on some university campuses abroad have been criticized for "improper influence over teaching and research, industrial and military espionage" (Starr, 2009, pp. 78-79). The Terracotta Army exhibition in London, as mentioned above, was criticized for its "government involvement". Is the audience in Montreal in favor of these comments? The responses to this question are as follows (Table 5):

Table 5. The audience's attitude towards the exhibition

\begin{tabular}{|c|c|c|c|c|c|}
\hline \multicolumn{2}{|c|}{ Which opinion about the exhibition do you agree on? } & Frequency & Percent & $\begin{array}{c}\text { Valid } \\
\text { Percent }\end{array}$ & $\begin{array}{l}\text { Cumulative } \\
\text { Percent }\end{array}$ \\
\hline Valid & $\begin{array}{l}\text { It is just a showcase of ancient Chinese culture, } \\
\text { promoting mutual understanding between } \\
\text { Canada and China. }\end{array}$ & 224 & 73.7 & 95.3 & 95.3 \\
\hline & $\begin{array}{l}\text { It is sort of China's overseas propaganda, } \\
\text { promoting China's ideology abroad." }\end{array}$ & 11 & 3.6 & 4.7 & 100.0 \\
\hline & Total & 235 & 77.3 & 100.0 & \\
\hline \multirow[t]{3}{*}{ Missing } & No Comments & 14 & 4.6 & & \\
\hline & System & 55 & 18.1 & & \\
\hline & Total & 69 & 22.7 & & \\
\hline Total & & 304 & 100.0 & & \\
\hline
\end{tabular}

The survey results show a strong majority of 74 per cent of respondents have positive views of the exhibition. This result indicates the audience generally does not interpret the exhibition politically. Instead, they are more likely to consider the exhibition as a window to learn about China and Chinese culture. While many Chinese scholars have argued that China's cultural exchange programs abroad should minimize government involvement to reduce concerns of political implications (K. Liu, 2011b; X. Wu, 2011), the exhibition of Terracotta Army in Montreal provides a counter example, as the exhibition was hosted by the Shaanxi Provincial Cultural Relics Bureau, which is a Chinese government institute. Therefore, a government-hosted cultural program does not necessarily incur political concerns, and the content of a cultural exchange program seems to be more important than the organizer.

\subsection{The Audience's Perception of Chinese Culture}

\subsubsection{Lack of Knowledge about China and Chinese Culture}

There is a hypothesis that China's rise, on the one hand, will draw more attention and interest to China and Chinese culture from the rest of the world; on the other hand, the Chinese government has invested a huge amount of money and into projecting images of China (D'Hooghe, 2011). As a result, overseas audiences should know about China and Chinese culture to a certain extent. However, the survey results countered this expectation (Table 6).

Table 6. The audience's knowledge about China and Chinese culture

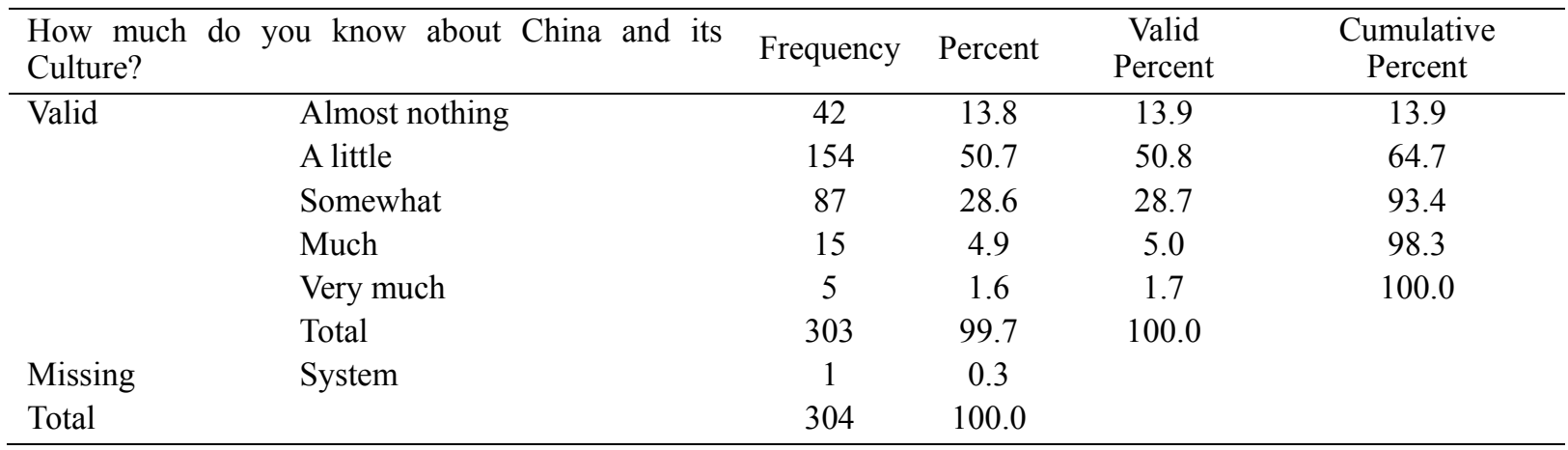


A solid majority of 60 per cent of the respondents say they only knew a little or nothing about China and Chinese culture. This result indicates a significant lack of knowledge and understanding of China by the foreign audience. Another survey in the United States generated the similar result that the American public knew very little about either tradition or contemporary Chinese culture (K. Liu, 2011a).Therefore, there is still a long way to go for China to tell its story to the world. As cultural diplomacy is supposed to be a long-term commitment (W. Hu, 2007), the goal of China's international cultural exchanges may also needs to be achieved over an extended period of time.

\subsubsection{Cultural Programs Abroad Remain Important to Learn about China}

The rapid development of new information and communication technologies (ICTs), particularly the internet, has given the audience additional means to become aware of China and Chinese culture. Do cultural exchange programs, such as the Terracotta Army exhibition, remain an important option for the audience to learn about China and Chinese culture? The responses to this question are as follows (Table 7):

Table 7. Means of learning about China and Chinese culture

\begin{tabular}{llll}
\hline & \multicolumn{2}{l}{ Responses } & \multirow{2}{*}{ Percent of Cases } \\
\cline { 2 - 3 } How do you know about China and its culture mostly? ${ }^{\text {a }}$ & $\mathrm{N}$ & \multicolumn{2}{l}{ Percent } \\
\hline Schooling & 72 & $12.1 \%$ & $23.7 \%$ \\
Newspapers & 68 & $11.4 \%$ & $22.4 \%$ \\
Broadcasting & 113 & $18.9 \%$ & $37.2 \%$ \\
Internet & 81 & $13.6 \%$ & $26.6 \%$ \\
Books & 84 & $14.1 \%$ & $27.6 \%$ \\
Magazines & 53 & $8.9 \%$ & $17.4 \%$ \\
Cultural exchange programs such as exhibitions, performances, etc. & 70 & $11.7 \%$ & $23.0 \%$ \\
Other & 56 & $9.4 \%$ & $18.4 \%$ \\
Total & 597 & $100.0 \%$ & $196.4 \%$ \\
\hline
\end{tabular}

a. Dichotomy group tabulated at value 1 .

The survey shows broadcasting, including radio and TV, is the most popular medium for the audience to learn about China and Chinese culture. In contrast to broadcasting's broader penetration rate, cultural exhibitions or performances have less advantage in terms of accessibility, as these cultural programs require on-site participation and the audience needs to buy tickets to obtain access in many cases. Notwithstanding these disadvantages, cultural programs remain as important as books, internet, schooling and newspapers.

\subsubsection{Chinese History: The Most Interesting Chinese Culture}

With more than five thousand years of continuous civilization, China has one of the world's oldest and most complex cultures, including philosophy, literature, history, arts, architecture, food, and so forth. Which component of the Chinese culture appeals to foreign audience the most? The responses to this question are as follows (Table 8):

Table 8. The most interesting Chinese culture to the audience

\begin{tabular}{cllll}
\hline \multirow{2}{*}{ Would you be interested in any of the following aspects of Chinese culture? } & \multicolumn{2}{l}{ Responses } & \multirow{2}{*}{ Percent of Cases } \\
\cline { 2 - 4 } & philosophy & $\mathrm{N}$ & Percent & \\
\hline literature & 100 & $13.0 \%$ & $33.0 \%$ \\
& history & 50 & $6.5 \%$ & $16.5 \%$ \\
& arts & 206 & $26.8 \%$ & $68.0 \%$ \\
& architecture & 169 & $22.0 \%$ & $55.8 \%$ \\
& food & 112 & $14.6 \%$ & $37.0 \%$ \\
& other & 113 & $14.7 \%$ & $37.3 \%$ \\
Total & & 19 & $2.5 \%$ & $6.3 \%$ \\
\hline
\end{tabular}

a. Dichotomy group tabulated at value 1 .

The survey shows what interests the audience the most is Chinese history (68\%). China is a large country full of historical stories and cultural heritages, which has cultivated a unique charm and everlasting curiosity for the 
audience. The presentation of China's historical culture is more likely to be accepted by audiences abroad. The cultural relics exhibitions, as one of the means to showcase China's historical culture, have served as a window for the audience to see China and Chinese culture. Even President Hu Jintao acknowledged that a cultural relic exhibition sometimes could "surpass a diplomat" (State Administration of Cultural Heritage, 2008).

\subsubsection{Art and Culture: The Most Interesting Contemporary Chinese Experience}

Notwithstanding that foreign audiences seem to be more interested in Chinese history and traditional culture, many Chinese scholars have argued that the presentation of contemporary China should become a priority, as it is more urgent for world audiences to learn what China has achieved at present than in the past (Qiao 2010). According to the Chinese Ministry of Culture, China's overarching strategy for international cultural exchanges also encourages the presentation of contemporary China to the world with particular emphasis on these achievements after China' s economic reforms in 1978 (Li 2010). What are the most interesting aspects of contemporary Chinese experiences for the audience? The responses to this question are as follows (Table 9):

Table 9. The audience's interest in contemporary Chinese experiences

\begin{tabular}{|c|c|c|c|}
\hline \multirow{2}{*}{$\begin{array}{l}\text { Besides ancient China, would you be interested in the following exhibitions of } \\
\text { contemporary China? }{ }^{\text {a }}\end{array}$} & \multicolumn{2}{|c|}{ Responses } & \multirow{2}{*}{$\begin{array}{l}\text { Percent } \\
\text { Cases }\end{array}$} \\
\hline & $\mathrm{N}$ & Percent & \\
\hline Politics & 60 & $12.3 \%$ & $19.9 \%$ \\
\hline Economy & 48 & $9.8 \%$ & $15.9 \%$ \\
\hline Art \& Culture & 182 & $37.3 \%$ & $60.3 \%$ \\
\hline People's Everyday Life & 155 & $31.8 \%$ & $51.3 \%$ \\
\hline other & 43 & $8.8 \%$ & $14.2 \%$ \\
\hline Total & 488 & $100.0 \%$ & $161.6 \%$ \\
\hline
\end{tabular}

a. Dichotomy group tabulated at value 1 .

The survey shows the audience is mostly interested in contemporary Chinese art and culture (60\%), as well as in Chinese people's everyday life (51\%), whereas they have much less interest in China's prevailing politics (20\%) and economy (16\%). The survey conducted in the United States generated the similar result (X. Wu, 2011) . Therefore, the Chinese government should focus on art, culture, and civic life in showcasing a profile of today's China to world audiences. Due to the wide ideological gap between China and the West, political contents should be minimized in China's international cultural exchanges (Zhao, 2009). As China's economic achievements are well known by the world, economy-related contents should not be of too much weight in the cultural exchange programs.

\subsection{The Audience's Perception of China's International Image}

\subsubsection{Substantial Neutral and Negative Views Persist towards China's Image}

According to the latest BBC World Service Country Rating Poll, Canadians' overall views of China have gone from leaning negative to leaning positive over the year 2011(BBC World Service, 2012), as China's positive economic influence impacts the world. Yet another opinion poll released by the Asia Pacific Foundation of Canada (2011) suggests only one in ten Canadians feels warmly towards China and other emerging Asian powers. How then does the audience in Montreal view China's image? The responses to this question are as follows (Figure 2): 


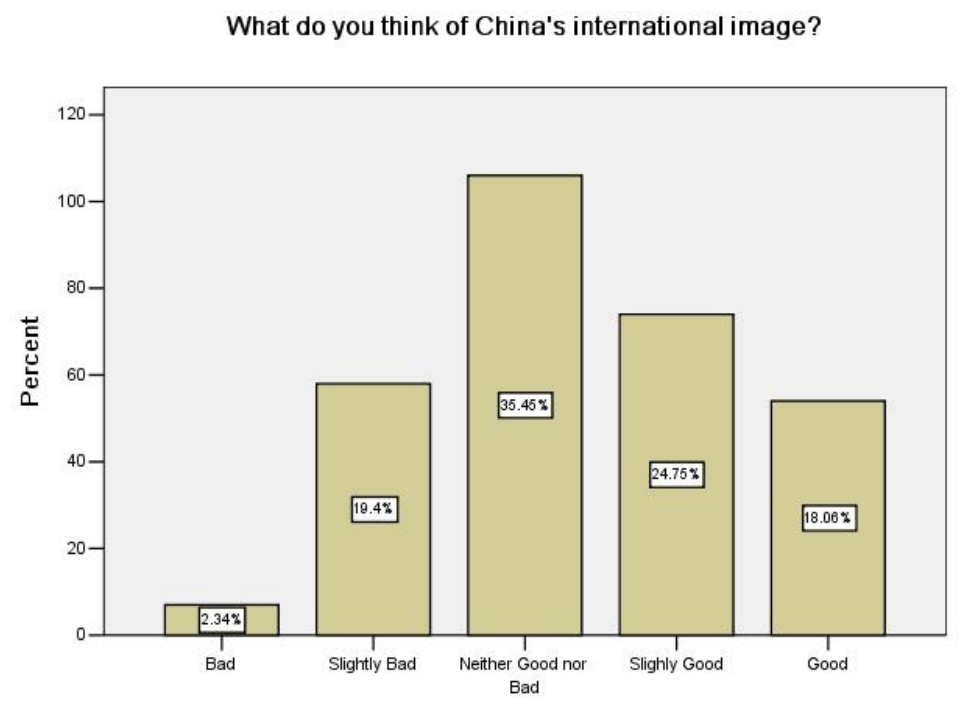

Figure 2. China's image in the international community

The responses to this question (Figure 2) show neutral attitudes make up the highest percentage (35\%) towards China's international image, followed by the slightly positive views (25\%) and very positive views (18\%); whereas the overall negative views, which include both the slightly negative and very negative views, are reported in more than one in five people surveyed. Firstly, this survey result indicated that China has made an substantial improvement upon its international image, as China's positive influence impacts the world. In spite of this, the portion of the audience on neutral ground is still most significant, which could have a major effect to the long-term trend of perceptions of China's image. Moreover, the amount of negative views of China remained considerable, which poses an alert to China's policy makers.

\subsubsection{Undecided Attitudes towards the "China threat" Theory}

The "China threat" argument is mainly grounded on the power transition theory and the successor-state image theory(Al-Rodhan, 2007; Jeffery, 2009). The former theory argues China's reemergence as a major power will inevitably pose a threat to the world order and stability by conflicting with the United States. The latter hypothesizes China will act as a successor to the former Soviet Union. The "China threat" theory certainly influences public views of China's image. A poll conducted by Pew Research Center (2011b) indicated at least seven-in-ten publics in Japan, the United States, Western Europe and Russia have negative views of China's "growing military power". Both Pew and Gallup polls found that China is the second "greatest enemies" to the United States (Pew Research Center, 2012; Newport, 2012). Meanwhile, "China's new economic power fans fear" too, according to a global poll conducted by the BBC World Service (2011). So far as Canadian public is concerned, the opinion poll released by the Asia Pacific Foundation of Canada (2011) suggests the number of Canadians that view the rise of China as a threat has increased over the years. How does the audience in Montreal respond to "China threat"? The responses are as follows (Figure 3): 


\section{“China's growth could be a threat to other countries." Do you agree?}

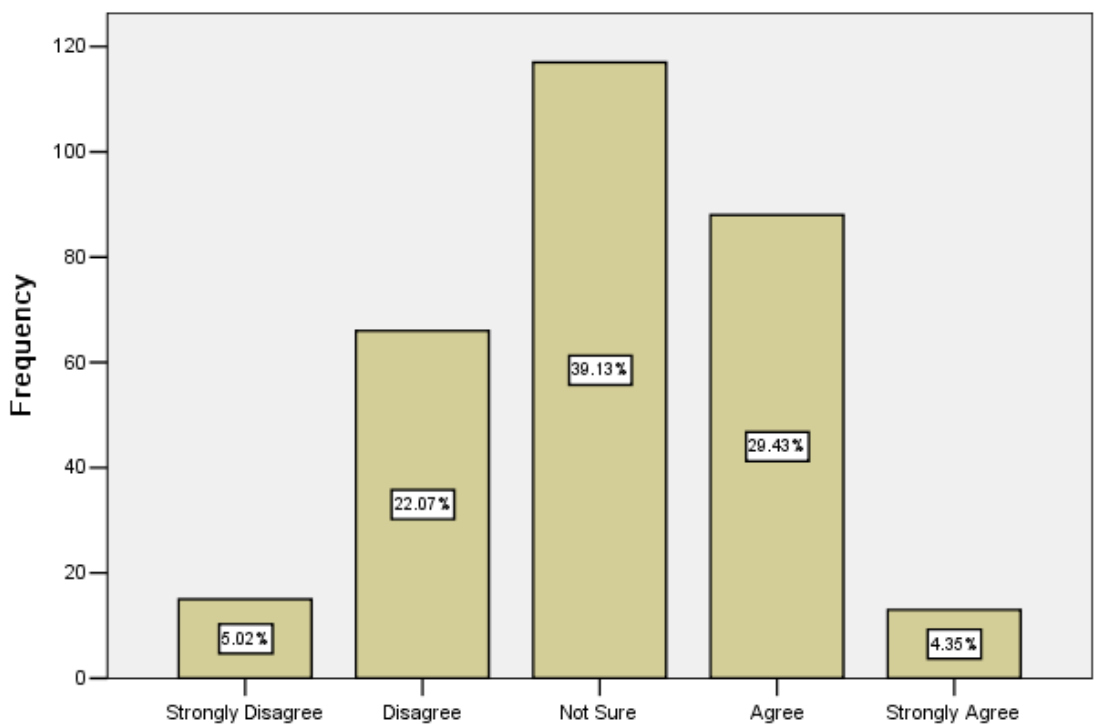

Figure 3. The audience's attitude towards the "China threat" theory

The survey shows the undecided respondents (39\%) make up the highest percentage of the audience surveyed. However, the portion of respondents who agree (34\%) China is a threat surpasses those who disagree $(27 \%)$. This result indicates China's increasing power indeed causes rising concerns among foreign publics. As a recent research project reported, "while many countries and regions are much more positive about China's rise than they were before, considerable nervousness and concern persists" (Yee, 2011). This said, China should maintain its endeavor in elaborating "China's peaceful development" policy to the world and convincing the world China is committed to building a "harmonious world" together with other countries (J. Yang, 2011).

\subsubsection{China's Political Image Mostly Disapproved}

As shown by the above figures, there are considerable negative views of China's image, and many respondents agree that China could be a threat to other countries. What are the factors bringing about negative images and fears of China? The responses to this question are as follows (Table 10):

Table 10. Factors bringing about negative images of China

\begin{tabular}{|c|c|c|c|c|c|}
\hline & & Frequency & Percent & Valid Percent & Cumulative Percent \\
\hline \multirow[t]{14}{*}{ Valid } & Tibet Issue & 2 & 0.7 & 3.6 & 3.6 \\
\hline & Human Rights Violations & 9 & 3.0 & 16.4 & 20.0 \\
\hline & Lack of Understanding & 2 & 0.7 & 3.6 & 23.6 \\
\hline & Lack of Democracy and Freedom & 20 & 6.6 & 36.4 & 60.0 \\
\hline & Poverty & 2 & 0.7 & 3.6 & 63.6 \\
\hline & Taiwan Issue & 1 & 0.3 & 1.8 & 65.5 \\
\hline & Media Coverage & 3 & 1.0 & 5.5 & 70.9 \\
\hline & Both Threat and Opportunity & 3 & 1.0 & 5.5 & 76.4 \\
\hline & Women's Right not Respected & 1 & 0.3 & 1.8 & 78.2 \\
\hline & Military Threat & 2 & 0.7 & 3.6 & 81.8 \\
\hline & Materialism & 1 & 0.3 & 1.8 & 83.6 \\
\hline & Pollution & 6 & 2.0 & 10.9 & 94.5 \\
\hline & Economic Threat & 3 & 1.0 & 5.5 & 100.0 \\
\hline & Total & 55 & 18.1 & 100.0 & \\
\hline Missing & System & 249 & 81.9 & & \\
\hline Total & & 304 & 100 & & \\
\hline
\end{tabular}

The survey shows the audience generally admires China's economic achievement. Some respondents wrote, for 
example, "impressive economic development", "people know china as an economic leader", etc. However, political issues are selected as the most negative factors of China's image by the audience, which has greatly neutralized the positive images of China. As one respondent writes, "there are great stories of innovation coming from China, but its history with human rights holds it back". There are many negative views of China's democracy, freedom as well, such as "lack of democracy", "depression of liberty" etc. China's leaders still have a long way to go in convincing the world publics that China has made considerable progress in terms of political freedom and human rights under the "socialist democratic politics" (Fang, 2007). "Tomorrow's China will be a country that fully achieves democracy, the rule of law, fairness and justice," as claimed by the Chinese premier Wen Jiabao in a speech in 2011 (Xinghua News Agency, 2011).

\subsubsection{International Cultural Exchanges Improve China's Image}

With international cultural exchanges, a country showcases its history, art, and culture to audiences abroad, which in turn helps audiences understand the country's national philosophy, ethics, values, heritages and traditions, etc. Furthermore, international cultural exchanges seem to help increase positive views of the country's influence abroad. The United Kingdom, Germany, France and Japan are well known for their successful international cultural promotions. These counties all have institutes specializing in international cultural exchanges, such as Germany's Goethe-Institute, UK's British Council, France's Institut Français, and Japan's Japan Foundation. In the past BBC World Service Country Rating Polls, all these countries have maintained mostly favorable ratings since the tracking began in 2005(BBC World Service, 2012). After watching the Terracotta Army exhibition, many within the surveyed audience indicate their great wonder and admiration for Chinese history, as well as their increased interest in Chinese culture. Is the audience in favor of the idea that cultural exchanges help to improve China's image? The responses to this question are as follows (Figure 4):

\section{Do you agree China's international cultural promotions help improve its image in the world?}

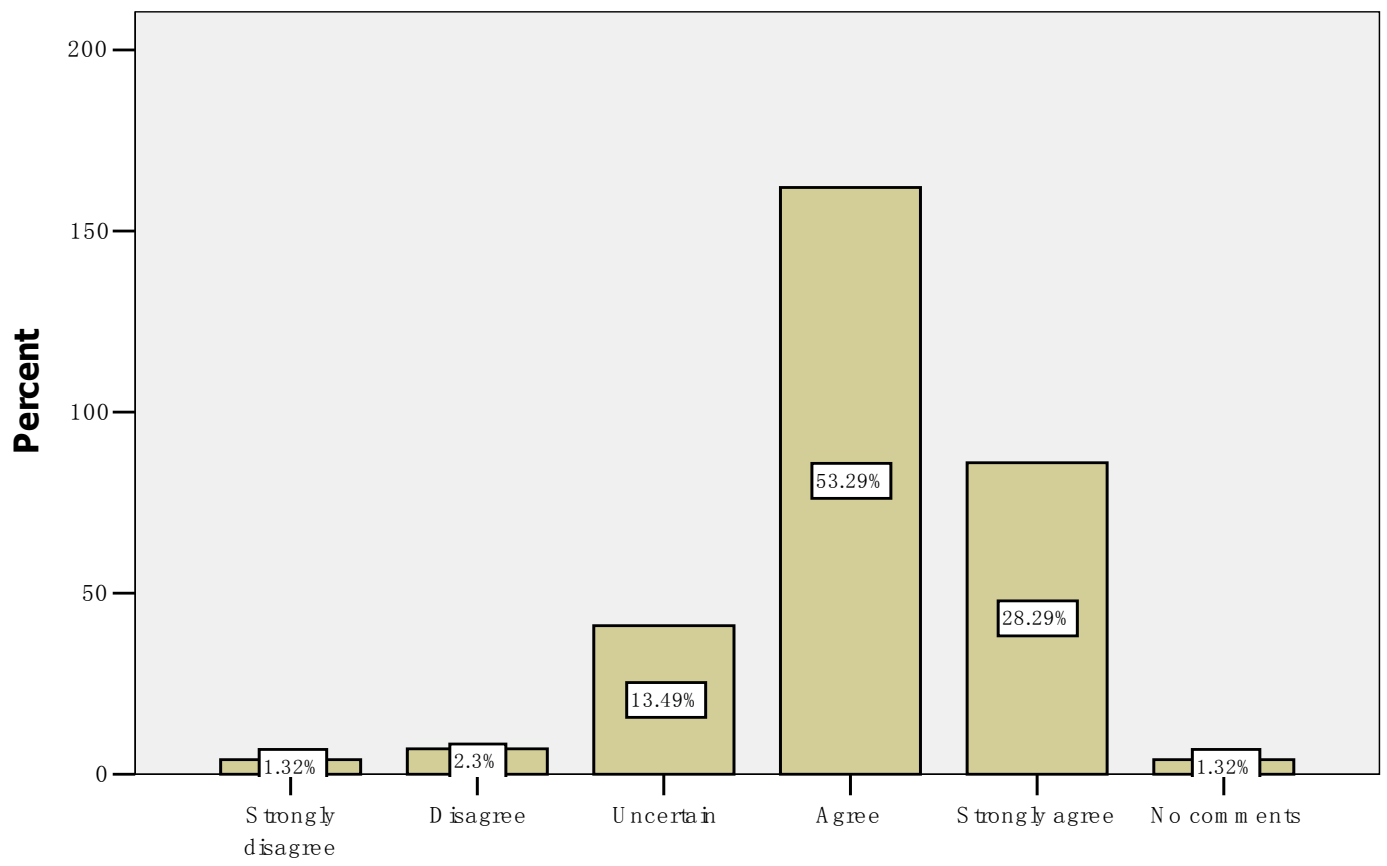

Figure 4. Audience's attitudes towards China's international cultural exchanges

The responses to this question show an overwhelming majority of 82 per cent of respondents who say China's international cultural exchanges help improve China's image in the world. This indicates the audience's general positive attitude towards China's cultural exchange programs abroad, and furthermore, the audience seems to have viewed China more positively after they learnt more about China and Chinese culture through these Chinese cultural exchange programs. 


\section{Conclusion}

In the second decade of the twenty-first century, China's further rise as a global power has drawn much attention as well as concern from the rest of the world. Now China has just commenced its twelfth Five-Year Plan, which is seen as another critical step towards China's "great renaissance." (Note 9) In a globalized world, it is evident that a nation state's image and reputation in the international community could impact its national interests both economically and politically. As considerable amount of negative views and criticisms persist in international opinion, China's international image is very likely to be deteriorated. To tell China's story and project positive images to the world, Chinese government has been proactive in cultural programs abroad, which is seen as part of China's cultural diplomacy within the spectrum of public diplomacy.

The survey results give little ground for optimism about China's international image. Despite slight pluralities having positive perceptions of China's international image, substantial neutral views and considerable negative views persist. Moreover, undecided respondents make up the highest percentage in viewing the "China threat" and the portion of the audience who agrees with the "China threat" surpasses those who disagree. All these factors could change the long-term trend and overturn the overall picture of China's image. Why does the audience have negative perception of China's image? I argue it is on the one hand based on facts, as China indeed suffers lots of social, political and environmental problems on its path to industrialisation, which inevitably causes concerns and worries across the world; but on the other hand, audience's opinion could also be influenced by some western media, scholars and policy makers, whose views of China sometimes could be very one-sided, as suggested by some empirical studies. (Note 10) In any case, the lack of knowledge about China is a root cause, as this survey suggests most of the audience has very limited knowledge about China and Chinese culture.

This said, the Chinese government should continue its endeavor in international cultural exchanges to tell China's story and reduce doubts and concerns about China's development. For foreign public, these programs provide additional sources of learning about China and Chinese culture. As this survey indicated, the majority views China's cultural exchange programs positively. What are the best strategies for China's international cultural exchanges? This survey suggests a two-pronged approach might be applicable to present both ancient China and cotemporary China to the world.

On the one hand, Chinese history should remain central in China's cultural programs abroad, communicating Chinese people's traditional value of peace and harmony. The survey results indicate that Chinese historical culture remains the most acceptable themes for audiences abroad. For foreign public, they may get to know China from different approaches, it is certainly important to see China through the lens of its history and culture, as China today has evolved from its past and Chinese historical legacies exert profound impact on Chinese people's philosophies and values today. Within China's traditional philosophies that are largely derived from Confucianism and Taoism, there are many doctrines addressing world peace and harmony. (Note 11) For example, "Seeking harmony is the most valuable principle in conducting the rite, which was cherished by the ancient sage kings in handling state affairs" (Confucius, 1994, p. 9), "Loving people and treating neighbors kindly are most valuable to a country" (Zuo, 1990, p. 33), and "All countries live in harmony" (Classic of History, p.14), just to name a few. The Chinese government has also stressed that China's path of peaceful development "carries forward the Chinese historical and cultural tradition" (Information Office 2011).

On the other hand, art and culture, as well as people's everyday life should be highlighted in presenting contemporary China to the world. This survey shows audience has little interest in China's politics and economy. To present contemporary Chinese experience to the world, cultural programs should not cover or varnish China's problems, avoiding being seen as "propaganda". Instead, authentic stories reflecting all aspects of Chinese society and culture should be displayed, helping foreign public understand transformations and changes taking place in China today, as well as China's policy of peaceful development and China's commitment to become a responsible nation and build a harmonious world together with other countries.

\section{Acknowledgments}

We gratefully acknowledge the support of the Montreal Museum of Fine Arts for permitting us to conduct the audience interview. The study is made possible by funding from Professor Marc Raboy, Beaverbrook Chair in Ethics, Media and Communications at McGill University, and the hospitality of Media@McGill, a hub of research based in the Department of Art History and Communication Studies at McGill University. We would also like to thank PhD candidate Gretchen King, Professor Marc Raboy and Professor Will Straw at McGill University for reviewing this manuscript. 


\section{References}

Adams, T. (2007, August 19 ). Behold the Mighty Qin. Retrieved September 20, 2011, from http://www.guardian.co.uk/artanddesign/2007/aug/19/art.china?INTCMP=SRCH

Al-Rodhan, K. R. (2007). A Critique of the China Threat Theory: A Systematic Analysis. Asian perspective, 31, 41-66.

Asia Pacific Foundation of Canada. (2011, April 15). APF Canada Poll Finds Few Canadians Feel Warmly Towards Asia's Rising Powers. Retrieved October 1, 2011, from http://www.asiapacific.ca/news/apf-canada-poll-finds-few-canadians-feel-warmly-towards-asia

BBC World Service. (2011, March 27). Rising Concern about China's Increasing Power: Global Poll. Retrieved May 10, 2012, from http://www.worldpublicopinion.org/pipa/pdf/mar11/BBCChina_Mar11_rpt.pdf

BBC World Service. (2012, May 10). Views of Europe Slide Sharply in Global Poll, While Views of China $\begin{array}{lllll}\text { Improve. } & \text { Retrieved } & \text { July } & 2012, & \text { from }\end{array}$ http://www.worldpublicopinion.org/pipa/pdf/may12/BBCEvals_May12_rpt.pdf

Blackburn, S. (2008a). Confucianism. In Oxford University Press, the Oxford Dictionary of Philosophy. Retrieved Ooctober 23, from http://www.oxfordreference.com/view/10.1093/acref/9780199541430.001.0001/acref-9780199541430-e-68 3

Blackburn, S. (2008b). Taoism. In Oxford University Press, The Oxford Dictionary of Philosophy. Retrieved October 23, 2012, from http://www.oxfordreference.com/view/10.1093/acref/9780199541430.001.0001/acref-9780199541430-e-30 42

Bureau of External Cultural Relations of Ministry of Culture. (2004). Cultural exchanges regulation. Retrieved October 22, 2011, from http://www.chinaculture.org/gb/cn_law/2004-06/28/content_49651.htm

D'Hooghe, I. (2011). The expansion of China's public diplomacy system. In J. Wang (Ed.), Soft power in China: public diplomacy through communication (pp. 19-35). New York: Palgrave Macmillan.

Dong, X., Wang, X., \& Li, Y. (2010). An Analyze of Korean Public's Attitudes and Perception of China's Rise. Contemporary International Relations, (10), 41-47, 58.

Fang, N. (2007). Stick to the road of socialist democratic politics with Chinese characteristics. Qiushi, (10), 13-17.

Gries, P. H., \& Crowson, H. M. (2010). Political orientation, party affiliation, and American attitudes towards China. Journal of Chinese Political Science, 15(3), 219-244. http://dx.doi.org/10.1007/s11366-010-9115-1

Guardian. (2007, September 15). China's cultural influence:Terracotta diplomacy. Retrieved September 25, 2011, from http://www.guardian.co.uk/commentisfree/2007/sep/15/china.comment

Guo, R. (2011, March 14). An interview of China's Vice Minister of the Ministry of Culture. Retrieved August 20, 2011, from http://www.ccdy.cn/zhuanti2011/2011lianghui/content/2011-03/14/content_817238_2.htm

Hu, J. (2009, April 27). Hu Jintao's speech at the Meeting Marking the 30th Anniversary of Reform and Opening Up. Retrieved November 14, 2011, from http://www.bjreview.com.cn/Key_Document_Translation/2009-04/27/content_194200.htm

Hu, W. (2007). A theoretical analysis of cultural diplomacy. Foreign Affairs Review, (03), 50-58.

Japanese Ministry of Defense. (2011, August 3). DEFENSE OF JAPAN 2011 (White Paper). Retrieved October 24, 2011, from http://www.mod.go.jp/e/publ/w_paper/2011.html

Jeffery, R. (2009). Evaluating the 'China threat': power transition theory, the successor-state image and the dangers of historical analogies. Australian Journal of International Affairs, 63(2), 309-324. http://dx.doi.org/10.1080/10357710902895186

Jiang, H., Qian, Z., \& Zhou, B. (Trans.). (1990). A complete interpretation of the Classic of History. Guiyang: Guizhou People's Press.

Johnston, R. C. (2007 September 11). The First Emperor at the British Museum:A platoon of China's terracotta warriors has landed in the British Musuem. Retrieved August 30, 2011, from $\mathrm{http} / / /$ www.timesonline.co.uk/tol/system/topicRoot/Terracotta_Army/Similar 
Khoo, N. (2011). Fear factor: Northeast Asian Responses to China's Rise. Asian Security, 7(2), 95-118. http://dx.doi.org/10.1080/14799855.2011.581601

Kurlantzick, J. (2007). Charm offensive: how China's soft power is transforming the world. New Haven: Yale University Press.

Lai, B., \& Xia, Y. (Trans.). (1994). Analects of Confucius with English Translation. Beijing: Sinolingua.

Langley, W. (2007, August 26 ). Terracotta Warriors with Feat of Clay. Retrieved September 25, 2011, from http://www.telegraph.co.uk/comment/personal-view/3642255/Terracotta-warriors-with-feat-of-clay.html

Li, H. (2010, March 3). An Interview with the Director of the Western Europe Section of the Foreign Relation Bureau of the Ministry of Culture. Southern Weekly. Retrieved March 3, 2011, from http://www.infzm.com/content/42046

Ling, M., \& Yujia, L. (2010). China's National Image in Global Public Opinion Surveys in 2009. Journal of China University of Geosciences (Social Sciences Edition), (03), 21-25, 85.

Liu, J., \& He, H. (2006). Image of china in world mainstream media. Beijing: Communication University of China Press.

Liu, K. (2011a). How party affiliation, media and education contribute to perception of China's image: "Americans' views of China" survey results II. International Communications (9), 40-41.

Liu, K. (2011b). Suggestions: "Americans' views of China" survey results III. International Communications, (10), 38-39.

Liu, X. (2010). Discrimination of Key Concepts in the Research of International Opinion. Contemporary Communications, (01), 39-41.

Long, G. (2007). Study on Developing Condition of Chinese Martial Art in Europe and Its Internationalization. China Sport Science and Technology, (06), 27-30, 90.

Miks, J. (2011, May 10). Vietnam Eyes China "Threat". Retrieved from http://the-diplomat.com/china-power/2011/03/28/vietnam-eyes-china-threat/

Newport, F. (2012, February 20). Americans Still Rate Iran Top U.S. Enemy. Retrieved May 19, 2012, from http://www.gallup.com/poll/152786/Americans-Rate-Iran-Top-Enemy.aspx

Ociepka, B. (2008). Public Diplomacy. In W. Donsbach (Ed.), The International Encyclopedia of Communication. Blackwell Reference Online: Blackwell Publishing.

Office of the Secretary of Defense. (2012, May ). Military and Security Developments Involving the People's Republic of China 2012. Retrieved July 12, 2012, from http://www.defense.gov/pubs/pdfs/2012_CMPR_Final.pdf

Paradise, J. F. (2009). China and international harmony: The role of Confucius Institutes in bolstering Beijing's soft power. Asian Survey, 49(4), 647-669. http://dx.doi.org/10.1525/as.2009.49.4.647

Pew Rearch Center. (2011b, January 12). Strengthen Ties with China, But Get Tough on Trade. Retrieved October 10, 2011, from http://pewresearch.org/pubs/1855/obama-more-popular-abroad-than-at-home

Pew Rearch Center. (2012, February 13). Ask the Expert: Public Opinion About the U.S. and China. Retrieved March 5, 2012, from http://pewresearch.org/pubs/2194/china-united-states-relations-xi-jinping-barack-obama-ask-the-expert

Pew Research Center. (2011a, January 24). How the U.S. Media Cover China. Retrieved October 15, 2011, from http://pewresearch.org/pubs/1867/media-coverage-china-news

Price, M. E., \& Dayan, D. (2008). Owning the Olympics : narratives of the new China. Ann Arbor: University of Michigan Press: University of Michigan Library.

Ran, J. (2010a). A review of literature on the image of China in the West (I). News Knowledge, (07), 34-36.

Ran, J. (2010b). A review of literature on the image of China in the West (II). News Knowledge, (08), 54-56.

Rothkopf, D. (2011, September 10). The China threat: considering the growing consensus. Retrieved from $\mathrm{http} / / /$ rothkopf.foreignpolicy.com/posts/2011/01/18/the_china_threat_considering_the_growing_consensus

Rutledge, P. B. (2008). The influence of media on core beliefs: The predisposition on Americans toward conflict with China before and after the 2008 Beijing Olympics. Ph.D. 3350578, Fielding Graduate University, 
California. Retrieved from http://search.proquest.com/docview/304840284?accountid=12339 ProQuest Dissertations \& Theses (PQDT) database.

Scobell, A. (2007). China's Soft Sell: Is the World Buying. China Brief, 7.

Shaw, I. S.-W. (2010). Charm offensive: Gauging global public opinion on China's rise. M. P. P., Georgetown University, District of Columbia. Retrieved from http://search.proquest.com/docview/603219022?accountid=12339 ProQuest Dissertations \& Theses (PQDT) database.

Standard \& Poor's Financial Services LLC. (2011, August 11). United States of America Long-Term Rating Lowered To 'AA+'. Retrieved October 15, 2011, from http://www.standardandpoors.com/ratings/articles/en/us/?articleType=HTML\&assetID=1245316815902

Starr, D. O. N. (2009). Chinese Language Education in Europe: the Confucius Institutes. European Journal of Education, 44(1), 65-82. http://dx.doi.org/10.1111/j.1465-3435.2008.01371.x

State Administration of Cultural Heritage. (2008, December 29). Cultural relics exhibitions abroad: A 30 years review. Retrieved October 23, 2011, from http://www.sach.gov.cn/publish/portal0/tab790/info16029_page4.htm

Sun, Y. (2009). Decoding China's image: A comparison of the coverage of China between the New York Times and the Times, 1993-2002. Beijing: World Knowledge Press.

Tian, J. (2002). An on the spot record of the Terracotta Army exhibitions abroad. Xi'an: Sanqin Press.

Tidy, C. (2010). "The First Emperor: China's Terracotta Army" and the Politics of Representation and Resistance. MASTER OF ARTS, Bowling Green State University, Bowling Green. Retrieved from http://etd.ohiolink.edu/view.cgi/Tidy\%20Charlotte.pdf?bgsu1276552047

UNESCO. (2006, June 7). Montreal, Canada appointed a UNESCO City of Design. Retrieved August 25, 2011, from http://portal.unesco.org/culture/en/ev.php-URL_ID=30945\&URL_DO=DO_TOPIC\&URL_SECTION=201 .html

Wang, J. (2007). An Empirical Study of Chinese and Japanese Soft Power:Textual Research on the Questionnaire Survey at Osaka Sangyo University. World Economics and Politics, (07), 28-36, 24.

Wang, X., \& Han, G. (2010). "Made in China" and national image: A content analysis of 30 years' coverage in American mainstream media. Journal of International Communication, (09), 49-55.

Wang, X., Guo, D., \& Li, X. (2010, November 30). An interview with the Minister of Culture: China is expanding its cultural exchanges with other countries. Retrieved September 20, 2011, from http://gb.cri.cn/27824/2010/11/30/5187s3073330.htm

Wang, Z., \& Yang, Y. (2009). Perception of China's Image by Public in Southeastern Asia: An Survey Analysis Contemporary International Relations, (05), 53-60, 62.

Wei, J. (2010). China's image in western media: a case study of western media's coverage of China's 60 years anniversary celebration. Media Observer, (01), 28-29.

Wei, X. (2002). Cultural diplomacy: an approach to achieve international strategy. Theory and Rerorm, (2), 90.

Wheeler, A. C. (2012). China's Public Diplomacy in Kenya: The Case of Chinese Language and Cultural Programs at the University of Nairobi Confucius Institute. Ph.D. 3513298, Howard University, District of Columbia. Retrieved from http://search.proquest.com/docview/1025695423?accountid=12339 ProQuest Dissertations \& Theses (PQDT) database.

Wingrove, J. (2008, June 9). Vancouver and Montreal among 25 most livable cities. Retrieved May 3, 2011, from http://www.theglobeandmail.com/life/article690643.ece

Wu, X. (2011). Exalting China's image: an empirical analysis of the questionnaires on teachings by Confucius schools at University of Massachusetts Boston and Bryant University. Foreign Affairs Review, (1), 89-102.

Wu, Y. (2009, September 29). Terracotta Army Exhibitions over 30 years. Retrieved August 15, 2011, from http://www.bmy.com.cn/template/xsb/show.aspx?SiteID=INDEX\&Code=\&ID=3573

Wu, Y., \& Ge, Q. (2011). An Investigation Report on the Effects of International Communication and Promotion of Chinese Culture. Journal of Yunnan Normal University (Teaching and Research on Chinese as a Foreign Language), (01), 82-87. 
Xie, T., \& Benjamin, P. I. (2010). Americans and the rise of China as a world power. Journal of Contemporary China, 19(65), 479-501. http://dx.doi.org/10.1080/10670561003666095

Xinghua News Agency. (2011, March 7). China's Foreign Minister noted China will construct vertical diplomatic framework in the next 5 to 10 years. Retrieved August 25, 2011, from http://news.xinhuanet.com/politics/2011h/2011-03/07/c_121157026.htm

Yang, J. (2011). Explore the new phase of China's public diplomacy. Qiushi, (04), 43-46.

Yang, X. (2011). Situations and Characteristics of Wushu Spread in Colleges. Wushu Science, (08), 3-5, 17.

Yee, H. S. (2011). China's rise: threat or opportunity? London; New York: Routledge.

Zhai, S., \& Li, C. (2009). A Cross-cultural Analysis on Pew's Poll on China's Image. Journal of Ningbo Radio \& TV University, (04), 102-106.

Zhang, Y. (2006). U.S. Media's Coverage on China.. International Journal of Diversity in Organisations, Communities \& Nations, 5(5), 43-50.

Zhao, Q. (2009). From Civilian Diplomacy to Public Diplomacy. Foreign Affairs Review, (05), 1-3.

Zuo, Q. (1990). A complete interpretation of the Chronicle of Zuo (S. Wang, X. Jin \& F. Wang, Trans.). Guiyang: Guizhou People's Press.

\section{Notes}

Note 1. For different points of view on the "China Threat", see Yee (2011).

Note 2. See Office of the Secretary of Defense (2012) and Japanese Ministry of Defense (2011)

Note 3. For more empirical studies on the western media's coverage of China, see J. Liu and He (2006), Xiuli Wang and Han (2010), Sun (2009) and J. Wei (2010).

Note 4. See (Ran, 2010a). (Ran, 2010b)

Note5. The scope of "international cultural exchanges" could be extremely broad. In this paper, it refers to China's cultural and artistic performances and exhibitions in foreign countries, in accordance with the scope defined by the Bureau of External Cultural Relations of Ministry of Culture (2004).

Note 6. See for example, Kurlantzick (2007), Paradise (2009), Price and Dayan (2008) and Scobell Scobell (2007).

Note 7. If a questionnaire has more than $15 \%$ of incoherent answers, it is deemed invalid.

Note 8 . In basic research, a reliability of 0.80 for the different measure involved is adequate (Nunnally 1967 , 226).

Note 9. "Great renaissance" is a phrase used by Chinese leadership to describe China's resurgence as a great nation that will soar to ever greater heights as long as all Chinese people stick together. See J. Hu (2009).

Note 10. See section 1.2

Note 11. Confucianism is the practical philosophy derived from the teachings of the ancient Chinese philosopher Confucius, influential in China and other Far Eastern countries. It teaches that harmony is found by following the right actions of piety and respect, religious ritual, and righteousness. See Blackbum (2008a). Taoism is the philosophy founded by the ancient Chinese philosopher Lao-Tzu. It stresses patience, simplicity, and the unity of humanity and the universe achieved through the proper balance of male and female principles. See Blackbum (2008b). 